\title{
Crop Yield Assessment from Remote Sensing
}

Paul C. Doraiswamy, Sophie Moulin, Paul W. Cook, and Alan Stern

\begin{abstract}
Monitoring crop condition and production estimates at the state and county level is of great interest to the U.S. Department of Agriculture. The National Agricultural Statistical Service (NASS) of the U.S. Department of Agriculture conducts field interviews with sampled farm operators and obtains crop cuttings to make crop yield estimates at regional and state levels. NASS needs supplemental spatial data that provides timely information on crop condition and potential yields. In this research, the crop model EPIC (Erosion Productivity Impact Calculator) was adapted for simulations at regional scales. Satellite remotely sensed data provide a real-time assessment of the magnitude and variation of crop condition parameters, and this study investigates the use of these parameters as an input to a crop growth model. This investigation was conducted in the semi-arid region of North Dakota in the southeastern part of the state. The primary objective was to evaluate a method of integrating parameters retrieved from satellite imagery in a crop growth model to simulate spring wheat yields at the sub-county and county levels. The input parameters derived from remotely sensed data provided spatial integrity, as well as a real-time calibration of model simulated parameters during the season, to ensure that the modeled and observed conditions agree. A radiative transfer model, SAIL (Scattered by Arbitrary Inclined Leaves), provided the link between the satellite data and crop model. The model parameters were simulated in a geographic information system grid, which was the platform for aggregating yields at local and regional scales. A model calibration was performed to initialize the model parameters. This calibration was performed using Landsat data over three southeast counties in North Dakota. The model was then used to simulate crop yields for the state of North Dakota with inputs derived from NOAA AVHRR data. The calibration and the state level simulations are compared with spring wheat yields reported by NASS objective yield surveys.
\end{abstract}

\section{Introduction}

Monitoring agricultural crop conditions during the growing season and estimating the potential crop yields are both important for the assessment of seasonal production. Accurate and timely assessment of particularly decreased production caused by a natural disaster, such as drought or pest infestation, can be critical for countries where the economy is dependent on the crop harvest. Early assessment of yield reductions could avert a disastrous situation and help in strategic planning to meet the demands. The

P.C. Doraiswamy and A. Stern are with the USDA, ARS, Hydrology and Remote Sensing Lab, Bldg 007, Rm 104/ BARC West, Beltsville, MD 20705 (pdoraiswamy@ hydrolab.arsusda.gov).

Sophie Moulin is with INRA/Unite Climat-Sol-Environnement, Domaine St paul, Site Agroparc, 84914 Avignon Cedex 9, France.

P.W. Cook is with the USDA, National Agricultural Statistical Service, Research and Development Division, 3251 Old Lee Highway, Rm 305, Fairfax, VA 22030-1504.
National Agricultural Statistics Service (NASS) of the U.S. Department of Agriculture (USDA) monitors crop conditions in the U.S. and provides monthly projected estimates of crop yield and production. NASS has developed methods to assess crop growth and development from several sources of information, including several types of surveys of farm operators. Field offices in each state are responsible for monitoring the progress and health of the crop and integrating crop condition with local weather information. This crop information is also distributed in a biweekly report on regional weather conditions. NASS provides monthly information to the Agriculture Statistics Board, which assesses the potential yields of all commodities based on crop condition information acquired from different sources. This research complements efforts to independently assess crop condition at the county, agricultural statistics district, and state levels.

In the early 1960s, NASS initiated "objective yield" surveys for crops such as corn, soybean, wheat, and cotton in States with the greatest acreages (Allen et al., 1994). These surveys establish small sample units in randomly selected fields which are visited monthly to determine numbers of plants, numbers of fruits (wheat heads, corn ears, soybean pods, etc.), and weight per fruit. Yield forecasting models are based on relationships of samples of the same maturity stage in comparable months during the past four years in each State. Additionally, the Agency implemented a midyear Area Frame that enabled creation of probabilistic based acreage estimates. For major crops, sampling errors are as low as 1 percent at the U.S. level and 2 to 3 percent in the largest producing States.

Accurate crop production forecasts require accurate forecasts of acreage at harvest, its geographic distribution, and the associated crop yield determined by local growing conditions. There can be significant year-to-year variability which requires a systematic monitoring capability. To quantify the complex effects of environment, soils, and management practices, both yield and acreage must be assessed at sub-regional levels where a limited range of factors and simple interactions permit modeling and estimation. A yield forecast within homogeneous soil type, land use, crop variety, and climate preclude the necessity for use of a complex forecast model.

In 1974, the Large Area Crop Inventory Experiment (LACIE), a joint effort of the National Aeronautics and Space Administration (NASA), the USDA, and the National Oceanic and Atmospheric Administration (NOAA) began to apply satellite remote sensing technology on experimental bases to forecast harvests in important wheat producing areas (MacDonald, 1979). In 1977 LACIE in-season forecasted a 30 percent shortfall in Soviet spring wheat production that came within 10 percent of the official Soviet estimate that came several months after the harvest (Myers, 1983).

Photogrammetric Engineering \& Remote Sensing Vol. 69, No. 6, June 2003, pp. 665-674.

0099-1112/03/6906-665\$3.00/0

(C) 2003 American Society for Photogrammetry and Remote Sensing 
The LACIE project used the Landsat Multispectral Scanner (MSS) data to identify crops and their harvested acreage. Global weather data from World Meteorological Organization (WMO) stations were used in simple crop models to predict yields. These models were primarily statistical models that correlated yields with parameters such as air temperature and precipitation. Ground-based data on crop identification, crop condition, and yields were used in crop classification and model forecasts. Completed in 1978, the LACIE project showed that remote sensing can provide timely information on foreign commodity production which was significantly more accurate than the data generated by existing data collection methods.

The successor to LACIE was a joint program for Agriculture and Resources Inventory Surveys Through Aerospace Remote Sensing (AgRISTARS) which began in 1978, and followed most of the same objectives with respect to crop inventory and production assessment (AgRISTARS Program, 1981). There were other areas investigated, which are outside of scope of this paper. During the six-year program, there were major advancements in automation of large area crop classification (Hixson et al., 1981) and crop condition assessment (Boatwright and Whitehead, 1986). A series of field experiments were sponsored by AgRISTARS to understand the spectral characteristics of major U.S. grain crops that led to improved accuracies in classification and better understanding of the link between temporal spectral changes and agronomics (Bauer et al., 1980; Daughtry et al., 1984; Gallo et al., 1985). Another area of focus was the use of deterministic models to predict crop yields. Doraiswamy et al. (1979) provided an inventory of various crop yield models, including statistical and deterministic methods for the project. The performance of deterministic models for large area forecasts depended on the availability of local climatic data with adequate spatial resolution. Use of remotely sensed data was limited to studying the temporal changes in vegetation condition such as crop growth and development. Cloud contamination further reduced the limited Landsat temporal coverage for the crop season, and crop information could not be used in yield models.

Integration of remotely sensed data in crop yield models evolved during the next decade of research based on field experiments and advances in biophysical modeling. The need for linking real-time remotely sensed data initiated research on retrieval of biophysical parameters from satellite imagery. This paper summarizes the recent advances in the integration of parameters retrieved from remotely sensing imagery in crop models and presents an example of its application for an operational program in the USDA. One objective of this study is to demonstrate a framework for scaling-up crop yield simulations using remote sensing data. Currently, the climate and satellite data are available within weeks of acquisition and can provide data for operational assessment of crop yields. The timely evaluation of potential yields is increasingly important because of the economic impact of agricultural products on world markets.

\section{Background}

Remote sensing technology applications for monitoring vegetation condition has been studied extensively during the past several decades, providing timely assessment of changes in growth and development of agricultural crops. The normalized difference vegetation index (NDVI) derived from the visible and near-infrared (NIR) bands of the NOAA AVHRR satellite has been successfully used to monitor vegetation changes at regional scales (Tucker et al.,1983). Temporal changes in the NDVI are related to net primary production (Malingreau et al., 1986; Goward et al., 1987; Prince,
1991). Tucker and Sellers (1986) provided a theoretical background to relate primary production estimates based on the absorption of photosynthetically active radiation (PAR) by the canopy. Satellite observations can also provide an estimate of biomass. Earlier field studies conducted by Daughtry et al. (1983) and Asrar et al. (1985) provided experimental validation of this theory that relates spectral reflectance to biomass production of vegetation at field and regional scales.

Using NDVI derived from NOAA AVHRR data to estimate crop yields is an extension of the above concept. Studies have shown that the seasonal accumulated NDVI values are correlated well with the reported crop yields in semi-arid regions (Groten, 1993). Doraiswamy and Cook (1995) further demonstrated that accumulating the NDVI values for spring wheat only during the grain-fill period improved the estimates of potential crop yields in North Dakota. Using a Landsat classification of spring wheat for North Dakota, a crop mask was developed to help retrieve the NDVI values for primarily spring wheat crop. Although the results were encouraging, the relationships seemed to be valid only for the study areas and required adjustment for differences in soil background and the mixture of crops in the area because of the low resolution $(1.1 \mathrm{~km})$ of the NOAA AVHRR data.

Physiology-based crop growth models have been used successfully for predicting crop yields at the field level (Engel et al., 1997; Sinclair et al., 1997). These models require numerous inputs that are specific to the crop, soil characteristics, management practices, and local climatic conditions. These models have had limited use because fewer inputs are generally available at larger than field scales. Additionally, satellite remote sensing technology has been shown to be capable of providing certain crop characteristics and a real-time snapshot of changes in conditions affected by weather related events. Growth models simulate biophysical processes in the soil-cropatmospheric system to provide a continuous description of growth and development. Combining such a growth model with input parameters derived from remotely sensed data provides spatial integrity as well as a real-time "calibration" to simulations of model parameters (Maas et al., 1988; Maas et al., 1992; Maas et al., 1993; Guerif et al., 1993; Moulin et al., 1995; Doraiswamy et al., 2001). Earlier studies conducted at field scales have shown that remotely sensed data could be incorporated in simulations of agricultural crop yields to calibrate or adjust parameters during the simulation period to ensure that the modeled and satellite observed conditions agree.

Several crop growth models were examined for their ability to predict yields for regional assessments with only a few climatic and management input parameters. Soil moisture conditions during the crop season are one of the key factors in determining crop yields in rainfed agriculture. Thus, a crop model with a robust and accurate soil-water budget component is required. The EPIC (Erosion Productivity Impact Calculator) model developed by Williams et al. (1984) was selected to simulate spring wheat crop growth and yield. The model includes weather simulation, hydrology, erosion-sedimentation, nutrient cycling, pesticide fate, plant growth, tillage, soil temperature, and crop and soil management components.

The EPIC model is a mechanistic growth model describing the potential growth of the crop as a function of solar irradiation, air temperature, precipitation, and crop characteristics. Potential biomass is adjusted daily as a function of five plant stress factors (water, temperature, nutrient, aeration, and root growth). The EPIC model has evolved over the past decade into a widely used model and has gone 
through rigorous testing under various environmental conditions. Its ability to simulate yields of grain sorghum, wheat (Steiner et al., 1987), and corn (Bryant et al., 1992) has been very satisfactory. In southern Alberta, Canada, yields of spring wheat and spring wheat rotations were simulated accurately by EPIC (Toure et al., 1995). Nutrient (total nitrogen, organic phosphorous, and carbon) predictions for a three-year rotation (cotton-grain sorghum-wheat) were also found satisfactory (Smith et al., 1990). Hydrologic processes, runoff, percolation, and evapotranspiration, simulated by the model, were in good agreement with observed values (Steiner et al., 1987; Meisinger et al., 1991; Edwards et al., 1994). However, conducting validation procedures is critical for specific crops in the study region before using simulated data in further analyses (Tanji, 1982; Addiscott and Wagenet, 1985).

The integration of remotely sensed data with a crop growth model can be achieved by using two distinct methods. In the first method, model initialization is done by estimating crop parameters from remote sensing data and using these parameters as a direct input to the growth model (Maas, 1988). Crop parameters successfully used in this method are measures of light interception by the canopy, namely, leaf area index (LAI) and crop canopy cover. In a second method, a time series of remotely sensed measurements is used to calibrate the crop growth model.

Maas (1988) adjusted the simulated values of LAI to match the LAI estimates from reflectance measurements observed from the Landsat satellite. The LAI was correlated with NDVI from imagery. The limitation here is that the regression between NDVI and the LAI is not constant at all locations in the same scene. This method is suitable for smaller study areas such as a watershed. This second approach can be improved by simulating LAI from satellite imagery using a radiative transfer model (Verhoef, 1984). The simulation requires satellite imagery with inputs of leaf optical properties and canopy geometry. Moulin et al. (1995) successfully used this approach, simulating LAI for wheat crop from temporal variation of spectral reflectance at field and local scales. Simulated LAI from SPOT satellite image was directly linked to a model to predict crop yields.

The objective of this research is to test the applicability of remote sensing data as a means of adjusting simulations of crop yields at the local level. A radiative transfer model provided the link between satellite data and crop growth model. This procedure also provides a mechanism for scaling-up from a point simulation to a spatial representation of variability in crop yields at regional scales. A geographic information system (GIS) is used to aggregate the data layers for determining the yields at the sub-county and county levels in North Dakota. This study initially focused on the 1994 crop season, and after the successful application of AVHRR data, three more years of data (1995, 1997, and 1998) were analyzed. The 1996 season was not analyzed because of excessive cloud cover during critical periods of crop development.

\section{Materials and Methods}

\section{Study Area}

Spring wheat is the predominant crop grown in the state of North Dakota, located in the northern Midwestern region of the U.S. Because spring wheat is grown under rain fed conditions, the seasonal variability in rainfall patterns contributes to the variability in crop yields from season to season. Other predominant crops cultivated in the study area included spring barley, sunflower, and corn. Pasture is generally found on the less productive soils. Farmers grow spring wheat in this area on soils dominated by loams and clayloams with dark to black soil surface and limy sub-soils or sandy loams and loams with sandy or gravelly substrata. The total spring wheat acreage in North Dakota reported by NASS/USDA was approximately 9.1 million acres (3.7 million ha) in 1994 (NDASS, 1995).

This research was conducted in two phases. In the first phase, the procedure of linking a radiative transfer model with a crop yield simulation model was evaluated at the sub-county level where yield data from local farms were collected. For the first phase of this study, Sargent, Ransom, and Richland counties in the southeastern corner of North Dakota were selected. The eastern part of the state has a greater amount of spring wheat because the soils and climatic conditions are less harsh than in the western part of the state. The rainfall in eastern North Dakota from April to September averages 355 to $457 \mathrm{~mm}$. Sargent and Ransom counties contain 120,000 acres $(50,000$ ha) each of spring wheat and Richland county contains 210,000 acres $(85,000$ ha) (NDASS, 1995). The Landsat TM data were used in this phase of the study to evaluate the potential for integrating parameters derived from remote sensing imagery into crop yield simulation models.

In the second phase of this study, the integration of remote sensing parameters with crop simulation models was extended to the entire state of North Dakota. The NOAA AVHRR provided almost daily coverage and was used for monitoring crop condition in North Dakota.

\section{Processing of Satellite Data}

Landsat TM image data for two clear days (28 May and 30 June 1994) over the three counties were processed. Imagery was in the UTM projection, and registration to map control points was accomplished by using the Land Analyses System software. Digital counts were calibrated to radiances to obtain surface reflectance. The NDVI for each pixel was calculated using the red and NIR reflectance as follows:

$$
\mathrm{NDVI}=(\mathrm{NIR}-\mathrm{RED}) /(\mathrm{NIR}+\mathrm{RED}) .
$$

For Landsat, the red (TM3) and NIR (TM4) bands are 0.63 to 0.69 and 0.76 to $0.90 \mu \mathrm{m}$, respectively. The red (Band 1) and NIR band (Band 2) for NOAA AVHRR are 0.58 to 0.68 and 0.725 to $1.1 \mu \mathrm{m}$, respectively.

For the second phase of the study, daily coverage of NOAA AVHRR data (1-km resolution) was acquired for the State of North Dakota. The first two bands of AVHRR data were screened for clouds, calibrated, and corrected for atmospheric attenuations using the $6 \mathrm{~S}$ model (Vermote and Roger, 1996). The AVHRR swath is $2048 \mathrm{~km}$ in width and is ideal for monitoring large areas. Only the center 1020 pixels were retrieved from this swath to minimize the distortion of pixels at the edge of the scene. The registration error of the AVHRR imagery is less than 1 pixel.

\section{Climate Data}

Daily maximum and minimum temperatures and precipitation were acquired from 79 stations. Stations are maintained and operated by NOAA's National Climatic Data Center (NCDC). In the first phase of this study, daily weather data were acquired from a total of five climate stations within the three counties (Sargent, Ransom and Richland). Additional weather data from stations in the surrounding counties were also used to extrapolate data for locations in the threecounty area. Solar radiation data is generally not available at the NCDC weather stations and were simulated using the standard equations applied for specific geographic coordinates. The ARC/INFO geographic information system (GIS) was the platform for maintaining all the data layers and spatial extrapolations were done within this environment. 


\section{Soils Data}

The major soil groups were identified from the General Soil Map of North Dakota and from the County Soil Survey Report published by the North Dakota Agricultural Experiment Station and the Natural Resources and Soil Conservation Service (SCS, 1991). Soil physical and chemical properties were obtained from the EPIC soils database for North Dakota. The digital form of the data was brought into the GIS and general soil association polygons were identified as the basic unit to run the crop growth model to obtain a regional yield.

Soils in the three-county study areas are, generally, nearly level to gently rolling with a thick black surface layer with calcareous, claypan, or wet subsoils. Surface texture varies from fine to coarse. Dominant soil groups in the area are moderately well drained loams and clay loams (FormanAastad, Barnes-Hamerly, Barnes-Svea, Garden-Glyndon, and Overly-Bearden). Embden-Tiffany and Hecla-Hamar groups are moderately well drained fine sandy loams with rapid permeability and low water holding capacity. Renshaw (fine loamy over sandy) is somewhat excessively drained and has moderately rapid permeability. The Fargo series consists of deep poorly drained fine texture soils with slow permeability and high water holding capacity.

\section{Data Organization}

A geographic information system (GIS) was used to organize, extract, and analyze the spatially distributed layers. The predominantly spring wheat areas were delineated from the land-use maps. The NDVI derived from satellite imagery was used to develop the cell level averages to run the crop yield model at county and state levels. The spring wheat crop classification for the three counties and the state were applied to retrieve crop specific temporal NDVI data. A more detailed description of the classification method is described in the Results and Discussion section of this paper. NDVI statistics of the wheat pixels were extracted for each soil type for within-county crop model simulations. Weather data required for the model simulations at the County and State levels were generated by interpolating data from weather stations. Soil class was the basic management units for crop yield simulations. Crop yields were simulated at $10-$ by $10-\mathrm{km}$ cells for the three-county study. Simulation for the State was conducted using average data for the county. Climate data for state-level simulation was based on interpolation between stations within the state and stations located at the border areas outside the state.

\section{The SAIL Radiative Transfer Model}

A one-dimensional radiative transfer model, SAIL (Verhoef, 1984), provided simulated canopy reflectance in the direction of the sensor. Zara et al. (1998) used SAIL to simulate LAI for pasture and range grasses from Landsat data. The SAIL model required information on LAI, leaf angle distribution (LAD), leaf reflectance and leaf transmittance, and background soil reflectance. In this study, leaf reflectance and transmittance parameters for the Landsat TM data used in this study for the visible band were 0.12 and 0.1 , respectively, and for the near-infrared (NIR) were 0.46 and 0.50 , respectively. Soil reflectance for the visible and NIR were 0.13 and 0.19, respectively. Earlier investigators have shown that leaf optical properties differ among spring wheat varieties (Pinter et al., 1985; Jackson et al., 1986). Other parameters required for the model included solar zenith and azimuth angles, sensor view angle, and proportions of direct and diffuse shortwave solar radiation. Solar angles are computed as a function of latitude, date, and time of the satellite overpass. The EPIC model simulated the daily LAI required as input to the SAIL model that simulated visible and
NIR bands for Landsat and AVHRR. In this research, optical properties of spring wheat varieties grown in North Dakota were selected based on prior studies.

\section{Crop Growth Model Calibration}

The EPIC model was selected for this research, and NDVI was the remotely sensed data that was used to integrate spatial information to the crop model. Crop simulation was conducted at the sub-county level by organizing data layers of climate, soil physical properties, surface reflectance, and NDVI in a GIS within each soil type, represented by a separate polygon. First, location parameters, weather data for the 1994 growing season, soils data, and crop specific parameters provided in the EPIC model were used as inputs to the model. In general, sowing and maturity dates of crops are available at the county level but not for model simulations at point locations. The model was initially run using the reported state average dates for planting and maturity to establish the number of growing degree days required from emergence to maturity. Once the growing-degree-days (base temperature of $0^{\circ} \mathrm{C}$ ) is established, only the planting date is required as input while maturity dates were automatically determined according to the specified number of growing degree-days from emergence. The planting date used in the study was the historic average date provided by the 1993 North Dakota State Statistical Report. The calibrated model was then used for simulation for the 1994, 1995, 1997, and 1998 simulations.

For regional assessments, data required for components such as tillage, erosion, and nutrient cycling was set to optimum conditions, and the model was used to simulate crop yields in response to soil moisture, temperature, and other climatic factors. The advantage of the EPIC model is that it can be set to run for minimum inputs to simulate crop growth and development processes at a daily time step for several different crops.

Model parameters are reinitialized in the calibration procedure for the crop yield model. Calibrations were performed for each soil association to adjust the maximum potential LAI of the crop, the leaf area decline rate (RLAD), and the time when green LAI begins to decline (DLAI). The calibration procedure is shown in Figure 1. The crop model is initially run with default parameters to generate LAI and crop yield. The resulting daily LAI is an input to the SAIL model to simulate reflectance in the RED and NIR spectral range of Landsat TM or AVHRR data. NDVI values calculated using simulated reflectance from the SAIL model are compared with NDVI derived from satellite imagery. The EPIC crop model parameters were adjusted for NDVI to be within 20 percent of the observed satellite data.

\section{Results and Discussion}

\section{Crop Classification and Crop Data}

Accurate location of the spring wheat in the county is an important consideration in obtaining accurate results. In the first phase of this research, the three southeast counties were classified for land use and crop types using Landsat TM data. USDA/NASS developed an accurate crop classification using four dates of 1994 Landsat TM data in southeastern North Dakota (Cook et al., 1996). The supervised classification was performed using ground information from the NASS June Agricultural Survey (JAS), to establish crop categories and develop clusters for the classification. Spring wheat was the most accurately classified crop within these counties with an accuracy of 87.2 percent for the NASS JAS data. The classification showed field boundaries that delineate well the transition from one group of crops to the other. Plate 1 shows the general phenological development 


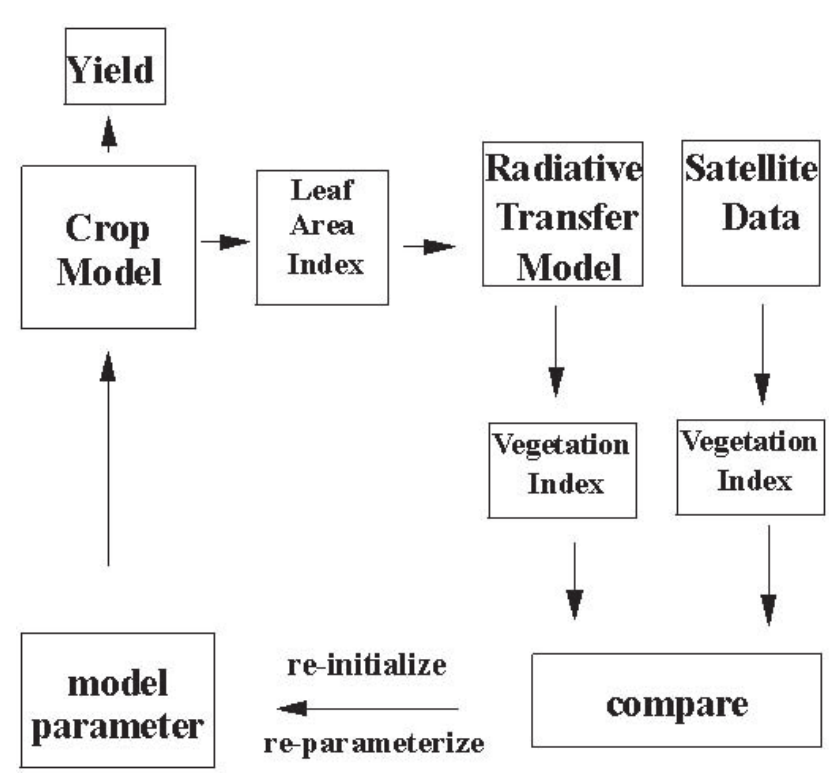

Figure 1. Schematic diagram of model calibration with satellite data and radiative transfer model.

of crops in the state of North Dakota. The categorization of spring wheat developed from the NASS State Agricultural Statistics segment data was relatively easier and more accurate than for other crops because of the early planting and maturity. Based on these analyses, a spring wheat crop mask was generated from the Landsat TM classification.

The classification developed from Landsat data was extended to the state level using a signature extension technique that identified similar signature classes between Landsat and AVHRR images (Stern et al., 2001). AVHRR data were used to develop a similar crop mask from spring wheat classification for the entire state of North Dakota. Plate 2 shows the spring wheat crop mask based on the percentage of spring wheat crop within a $1-\mathrm{km}$ pixel. In this study, only pixels that were categorized to have greater than 50 percent spring wheat were used for retrieval of

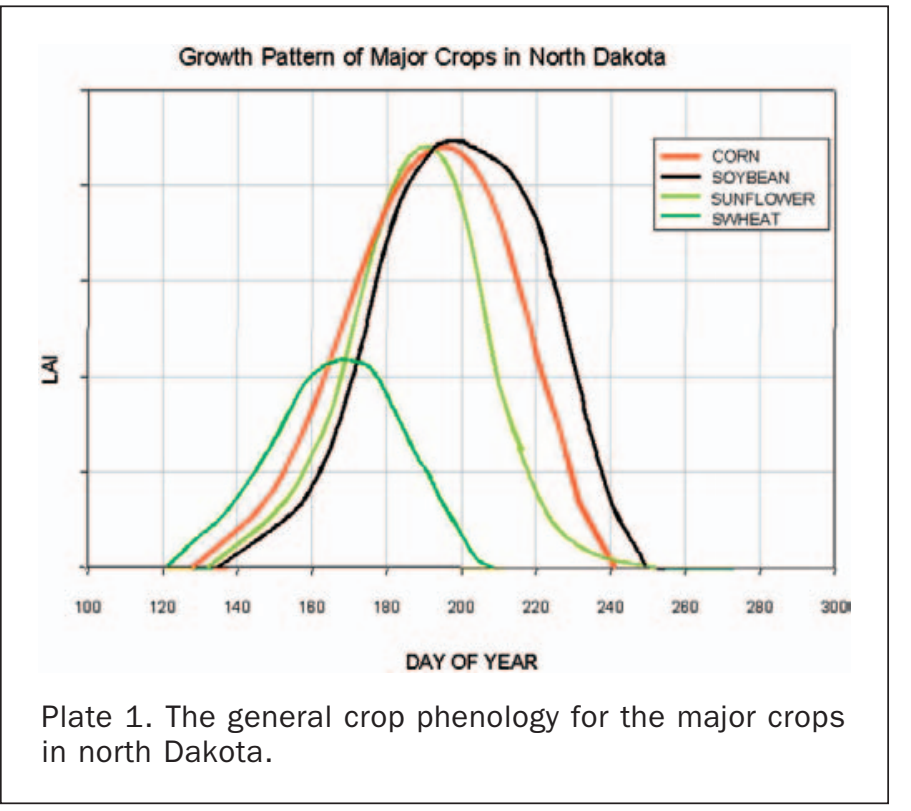

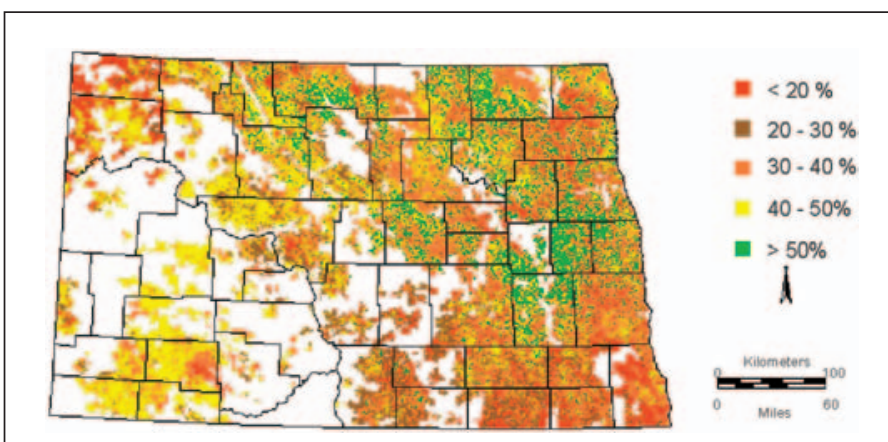

Plate 2. Classification of spring wheat as percentage of the NOAA AVHRR pixel (1-km resolution).

NDVI values. To improve the classification, areas of intensive agriculture defined by NASS stratum were used. The AVHRR crop mask is used primarily to obtain a conservative assessment of temporal changes in spring wheat crop within each county. Spring wheat crop acreage cannot be assessed from AVHRR data because of the low pixel resolution. There was no attempt to separate the spring barley and durum wheat crop cultivated in the state, contributing to a much lower acreage compared to spring wheat.

\section{Sensitivity Analyses}

Remotely sensed satellite data enhanced crop yield simulations in several ways. A sensitivity analyses was done to understand the role of parameters that can be retrieved from remotely sensed data. This would be the critical role of remotely sensed data in crop yield simulation for regional yield assessment. NASS reports provide the average planting dates only at the state level and not specific to a county. The two model parameters, DLAI and RLAD, are first assessed using remotely sensed satellite data prior to setting the planting date. As part of the procedure to fit simulated NDVI to a satellite observed value, the planting date is adjusted for the grid or management unit in the case within county simulations. When a suitable fit is attained, the planting date is set. A sensitivity analysis is performed by selecting a range of possible planting dates, potential maximum LAI $\left(\mathrm{LAI}_{\max }\right)$, RLAD, and DLAI values for spring wheat cultivated in North Dakota. The 1994 climate data used for these analyses and the model responses may vary slightly from one year to the next due to differences in the amount of rainfall and the temporal variations.

Table 1 shows the effect of three planting dates on spring wheat yields for different $\mathrm{LAI}_{\max }$ for three selected counties. The range of $\mathrm{LAI}_{\max }$ expected under extreme conditions of drought and ample water conditions are between 1.5 and 3.5, respectively, for a typical LRAD value of 1.5. The yield (tonnes/hectare) variation for the same planting dates across different $\mathrm{LAI}_{\max }$ was greater than the variation for planting dates between 10 April and 20 May. At later planting dates the model consistently predicted slightly lower yields, and these differences were greater at higher $\mathrm{LAI}_{\max }$. Total rainfall between January and August was about $400 \mathrm{~mm}$ in 1994 and the soil moisture was not limiting and therefore higher $\mathrm{LAI}_{\max }$ of 3.5 produced yields. Yields for early plantings were uniformly higher than late plantings because the grain fill periods occurred during optimum temperature conditions in July rather than in August.

The leaf area for grain crops declines due to leaf senescence as the crop approaches physiological maturity. Leaf senescence begins with yellowing of the older leaves 
Table 1. Effect of Planting Date on Spring Wheat Yields for Different leVels of Potential Maximum Leaf Area Index (LAI max) for Model Parameters $\mathrm{RLAD}=1.5$ AND DLAI $=0.6$

\begin{tabular}{|c|c|c|c|c|c|}
\hline County & Planting Dates & $\begin{array}{c}\mathrm{LAI}=1.5 \\
\text { t/ha }\end{array}$ & $\begin{array}{c}\mathrm{LAI}=2.5 \\
\mathrm{t} / \mathrm{ha}\end{array}$ & $\begin{array}{c}\mathrm{LAI}=3.5 \\
\mathrm{t} / \mathrm{ha}\end{array}$ & Harvest Dates \\
\hline Cass & $\begin{array}{l}10 \mathrm{Apr} \\
20 \mathrm{Apr} \\
30 \mathrm{Apr} \\
10 \mathrm{May} \\
20 \mathrm{May}\end{array}$ & $\begin{array}{l}1.58 \\
1.50 \\
1.44 \\
1.40 \\
1.33\end{array}$ & $\begin{array}{l}2.09 \\
2.00 \\
1.93 \\
1.86 \\
1.78\end{array}$ & $\begin{array}{l}2.43 \\
2.32 \\
2.25 \\
2.17 \\
2.08\end{array}$ & $\begin{array}{l}26 \text { Jul } \\
31 \text { Jul } \\
02 \text { Aug } \\
07 \text { Aug } \\
12 \text { Aug }\end{array}$ \\
\hline Pembina & $\begin{array}{l}10 \mathrm{Apr} \\
20 \mathrm{Apr} \\
30 \mathrm{Apr} \\
10 \mathrm{May} \\
20 \mathrm{May}\end{array}$ & $\begin{array}{l}1.81 \\
1.77 \\
1.73 \\
1.72 \\
1.73\end{array}$ & $\begin{array}{l}2.40 \\
2.36 \\
2.32 \\
2.29 \\
2.30\end{array}$ & $\begin{array}{l}2.74 \\
2.71 \\
2.68 \\
2.65 \\
2.67\end{array}$ & $\begin{array}{l}07 \text { Aug } \\
11 \text { Aug } \\
14 \text { Aug } \\
20 \text { Aug } \\
25 \text { Aug }\end{array}$ \\
\hline Williams & $\begin{array}{l}10 \mathrm{Apr} \\
20 \mathrm{Apr} \\
30 \mathrm{Apr} \\
10 \mathrm{May} \\
20 \mathrm{May}\end{array}$ & $\begin{array}{l}1.84 \\
1.73 \\
1.69 \\
1.68 \\
1.61\end{array}$ & $\begin{array}{l}2.45 \\
2.32 \\
2.27 \\
2.24 \\
2.14\end{array}$ & $\begin{array}{l}2.84 \\
2.70 \\
2.65 \\
2.60 \\
2.47\end{array}$ & $\begin{array}{l}30 \text { Jul } \\
04 \text { Aug } \\
06 \text { Aug } \\
11 \text { Aug } \\
17 \text { Aug }\end{array}$ \\
\hline
\end{tabular}

and proceeds from the lower leaves towards the top of the canopy. In most grain crop, the LAI declines linearly after grain filling begins. The model parameter DLAI defines the point in the growing season when leaf area begins to decline due to senescence. The typical range of DLAI for crops is between 0.5 and 0.8 , for leaf senescence beginning between 50 to 80 percent, respectively, of the crop season. Table 2 describes the effect of DLAI for different planting dates on the final yields.

The combined influence of planting dates on the time at which the green LAI begins to decline (DLAI) is shown in Table 2. Later planting dates produced slightly lower yields, which is probably a response to soil moisture conditions, these differences are greater when LAI is higher. At higher $\mathrm{LAI}_{\max }$ (3.5), there is a greater difference in yields between DLAI for later planting dates. The influence of limiting soil moisture conditions at mid-season may reduce the potentially higher yields when the LAI is high. A crop with an early planting date, and LAI of 3.5, requires a greater amount of soil moisture throughout the season. Adequate soil moisture during the vegetative growth period, followed by limited available soil moisture, results in plant water stress at grain-fill, thus reducing yields.

The effect of increasing LRAD (the leaf area decline rate) parameter is shown in Table 3. For earlier planting dates (10 April and 20 April) there is no significant difference in yields. However for a May planting date, there is a decline in yields because the higher decline ( RLAD $=1.5$ ) in LAI reduces the grain-fill period. The model response is consistent and suggests that later planting dates reduces yield because of lower moisture conditions.

\section{Crop Yield Simulation}

The use of remotely sensed imagery to monitor crop growth and development has been demonstrated in many earlier studies. Methods for using this information in crop models to calibrate or modify simulations have been investigated at field scale studies by Moulin et al., (1995). This research proceeds to the next step in developing and adapting these techniques of crop yield simulations to the regional level. The 1994 North Dakota State Statistical Reports published that planting dates for spring wheat began in mid April and

Table 2. The Effect of Planting Date on Spring Wheat Yields for Williams County When the Initiation of Leaf AREa Decline (DLAl) Is Set to Begin at Different Periods During the Crop Season. The Model Parameter RLAD $=1.5$

\begin{tabular}{|c|c|c|c|c|c|}
\hline $\begin{array}{c}\text { Parameter } \\
\text { DLAI }\end{array}$ & Planting Dates & $\begin{array}{c}\mathrm{LAI}=1.5 \\
\mathrm{t} / \mathrm{ha}\end{array}$ & $\begin{array}{c}\mathrm{LAI}=2.5 \\
\mathrm{t} / \mathrm{ha}\end{array}$ & $\begin{array}{c}\mathrm{LAI}=3.5 \\
\mathrm{t} / \mathrm{ha}\end{array}$ & Harvest Dates \\
\hline 0.50 & $\begin{array}{l}15 \text { Apr } \\
25 \text { Apr } \\
05 \text { May } \\
15 \text { May } \\
25 \text { May }\end{array}$ & $\begin{array}{l}1.65 \\
1.54 \\
1.50 \\
1.45 \\
1.36\end{array}$ & $\begin{array}{l}2.21 \\
2.07 \\
2.02 \\
1.94 \\
1.83\end{array}$ & $\begin{array}{l}2.58 \\
2.43 \\
2.37 \\
2.27 \\
2.14\end{array}$ & $\begin{array}{l}31 \mathrm{Jul} \\
05 \mathrm{Aug} \\
07 \mathrm{Aug} \\
17 \mathrm{Aug} \\
23 \mathrm{Aug}\end{array}$ \\
\hline 0.60 & $\begin{array}{l}15 \text { Apr } \\
25 \text { Apr } \\
05 \text { May } \\
15 \text { May } \\
25 \text { May }\end{array}$ & $\begin{array}{l}1.89 \\
1.79 \\
1.76 \\
1.71 \\
1.58\end{array}$ & $\begin{array}{l}2.51 \\
2.39 \\
2.35 \\
2.26 \\
2.09\end{array}$ & $\begin{array}{l}2.92 \\
2.77 \\
2.73 \\
2.60 \\
2.41\end{array}$ & $\begin{array}{l}31 \text { Jul } \\
05 \text { Aug } \\
07 \text { Aug } \\
17 \text { Aug } \\
23 \text { Aug }\end{array}$ \\
\hline 0.70 & $\begin{array}{l}15 \text { Apr } \\
25 \text { Apr } \\
05 \text { May } \\
15 \text { May } \\
25 \text { May }\end{array}$ & $\begin{array}{l}2.14 \\
2.05 \\
2.02 \\
1.94 \\
1.75\end{array}$ & $\begin{array}{l}2.83 \\
2.71 \\
2.67 \\
2.54 \\
2.29\end{array}$ & $\begin{array}{l}3.26 \\
3.12 \\
3.07 \\
2.88 \\
2.61\end{array}$ & $\begin{array}{l}31 \mathrm{Jul} \\
05 \mathrm{Aug} \\
07 \mathrm{Aug} \\
17 \mathrm{Aug} \\
23 \mathrm{Aug}\end{array}$ \\
\hline 0.80 & $\begin{array}{l}15 \text { Apr } \\
25 \text { Apr } \\
05 \text { May } \\
15 \text { May } \\
25 \text { May }\end{array}$ & $\begin{array}{l}2.42 \\
2.30 \\
2.26 \\
2.12 \\
1.91\end{array}$ & $\begin{array}{l}3.17 \\
3.02 \\
2.96 \\
2.76 \\
2.47\end{array}$ & $\begin{array}{l}3.63 \\
3.45 \\
3.37 \\
3.08 \\
2.77\end{array}$ & $\begin{array}{l}31 \mathrm{Jul} \\
05 \mathrm{Aug} \\
07 \mathrm{Aug} \\
17 \mathrm{Aug} \\
23 \mathrm{Aug}\end{array}$ \\
\hline
\end{tabular}


Table 3. Yield Response for Williams County at Several LeVels of the LAI Decline Rate RLAD With a Constant DLAI $=0.6$

\begin{tabular}{|c|c|c|c|c|c|}
\hline $\begin{array}{l}\text { Parameter } \\
\text { RLAD }\end{array}$ & Planting Dates & Day & $\begin{array}{c}\mathrm{LAI}=1.5 \\
\mathrm{t} / \mathrm{ha}\end{array}$ & $\begin{array}{c}\mathrm{LAI}=2.5 \\
\mathrm{t} / \mathrm{ha}\end{array}$ & $\begin{array}{c}\mathrm{LAI}=3.5 \\
\mathrm{t} / \mathrm{ha}\end{array}$ \\
\hline 0.50 & $\begin{array}{l}10 \mathrm{Apr} \\
20 \mathrm{Apr} \\
30 \mathrm{Apr} \\
10 \mathrm{May} \\
20 \mathrm{May}\end{array}$ & $\begin{array}{l}100.00 \\
110.00 \\
120.00 \\
130.00 \\
140.00\end{array}$ & $\begin{array}{l}2.00 \\
1.91 \\
1.86 \\
1.84 \\
1.73\end{array}$ & $\begin{array}{r}39.40 \\
2.52 \\
2.47 \\
2.42 \\
2.26\end{array}$ & $\begin{array}{r}45.40 \\
2.91 \\
2.84 \\
2.77 \\
2.57\end{array}$ \\
\hline 0.60 & $\begin{array}{l}10 \mathrm{Apr} \\
20 \mathrm{Apr} \\
30 \mathrm{Apr} \\
10 \mathrm{May} \\
20 \mathrm{May}\end{array}$ & $\begin{array}{l}100.00 \\
110.00 \\
120.00 \\
130.00 \\
140.00\end{array}$ & $\begin{array}{l}1.91 \\
1.81 \\
1.77 \\
1.75 \\
1.67\end{array}$ & $\begin{array}{l}2.53 \\
2.41 \\
2.36 \\
2.32 \\
2.20\end{array}$ & $\begin{array}{l}2.94 \\
2.80 \\
2.74 \\
2.69 \\
2.52\end{array}$ \\
\hline 1.50 & $\begin{array}{l}10 \mathrm{Apr} \\
20 \mathrm{Apr} \\
30 \mathrm{Apr} \\
10 \mathrm{May} \\
20 \mathrm{May}\end{array}$ & $\begin{array}{l}100.00 \\
110.00 \\
120.00 \\
130.00 \\
140.00\end{array}$ & $\begin{array}{l}1.84 \\
1.73 \\
1.69 \\
1.68 \\
1.61\end{array}$ & $\begin{array}{l}2.45 \\
2.32 \\
2.27 \\
2.24 \\
2.14\end{array}$ & $\begin{array}{l}2.84 \\
2.70 \\
2.65 \\
2.60 \\
2.47\end{array}$ \\
\hline
\end{tabular}

continued through the first week of June, and crop maturity began in early July and continued through the end of August. For areas in the southern part of the state where the earliest sowing occurs, crops emerged by the first week in May. Flowering occurred by the second week of June and the crop reached maturity by the first week in July for the earliest planting dates. Simulation of crop growth using the earliest planting date and growing degree days of thirteen hundred from emergence to maturity agreed very well with the observed data provided by NASS reports.

Model simulation of crop growth was calibrated with remotely sensed data for the major soil types within each county where spring wheat was cultivated. In the first phase of this study, the crop yield simulations were conducted for Sargent, Ransom, and Richland counties. Plate 3 shows the STATSGO soil classification and results of yield simulation with inputs from two Landsat images. Crop yield simulations were made at $10-\mathrm{km}^{2}$ grids, and the results were integrated to obtain yield for each soil class. The 1994 spring wheat yields for the three counties varied from 0.62 to 3.0 tonnes/hectare ( $\mathrm{t} / \mathrm{ha}$ ), depending on soil types and seasonal patterns of rainfall. Simulated yields were aggregated to obtain the weighted county level yields. The model was calibrated with the reported yields from four farms cooperating with the NASS survey program.

The calibrated model was then used to simulate yields for each county. The state-level spring wheat crop mask was applied to obtain a county average NDVI from cloudfree AVHRR images during the growing season. Simulations were run for each county using the climatic data available from NOAA stations within the county. Plate 4 shows the results of the simulations for the 1994 season. The range of yields was from 1.3 to 2.7 t/ha. In general, the eastern part of the state had higher levels of yield than did the western part, which has less annual rainfall. In 1994 the rainfall was more sporadic, and there were counties with higher yields in the western part of the state.

Figure 2 is the regression analysis of models simulated and NASS reports on crop production for the four seasons, 1994, 1995, 1997, and 1998 shown with a 95 percent confidence interval. Simulations were not conducted for the 1996 crop season because the three clear daily AVHRR images were not available during critical crop growth periods. Comparisons of total production were made for each county because this is the level at which NASS production is reported. Analysis was performed for individual years to study the consistency in model performance from one year to the next when remotely sensed data were used in the model.
Figure 2a shows the range of R-square between 0.69 and 0.90 for reported and model simulations of crop production without inputs from satellite imagery. The R-square was between 0.8 and 0.96 for model simulations using inputs from satellite imagery (Figure 2b). A closer evaluation suggests that the simulations without inputs from satellite imagery were not consistent from year to year compared to results when remotely sensed inputs were used in the model. Other model inputs may contribute to the estimates, and these errors may vary between seasons because the model responses are based on environmental variables. Among the four years studied, the lowest regression coefficient was for 1995 in both cases, with and without remotely sensed data. Inputs from remotely sensed data to the model adjusts the planting date and temporal dynamics of LAI that is consistent with the actual crop growth conditions. These are the major advantages in using satellite imagery which may compensate for simulation errors associated with planting date, temporal changes in LAI, time of LAI decline after its peak, and rate of senescence. The assumptions in these assessments are that all spring wheat varieties cultivated in North Dakota have the same average response to environmental conditions and the same length of growing season.

The spring wheat production for counties are mostly within 10 percent of the NASS reports. The outliers sometimes show large differences between reported modelsimulated productions (Figure 2b). Large differences may be attributed to a combination of errors associated with misclassification using AVHRR data and model input parameters such as planting dates. Yield reducing factors that may contribute to errors in model simulations could be associated with disease and pest infestation that are unaccounted for in remote sensing or the crop model. Another factor that has an effect on yield is the presence of weeds, which cannot be assessed from lower resolution satellite imagery. A major consideration to be noted is that NASS yield statistics are designed to provide very accurate estimates at the State level. County level yields are estimated and adjusted to sum to the State level.

\section{Conclusion}

This research successfully demonstrates a method for integrating remotely sensed data and a crop simulation for monitoring crop growth and yields of spring wheat at the county and state level in North Dakota. In the first phase of this research, Landsat data were used to assess spring wheat yields for three counties, and the model simula- 


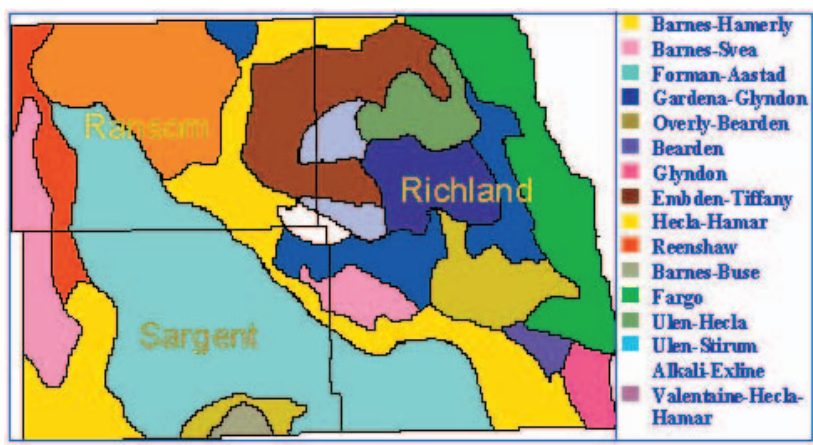

(a)

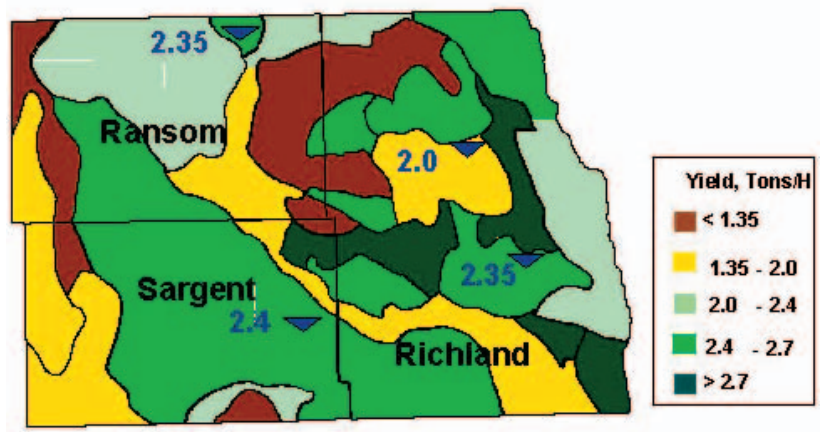

Yields reported at survey farms

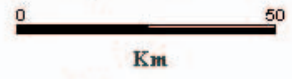

(b)

Plate 3. Soil association map (a) from STATSGo for Ransom, Sargent, and Richland counties, and (b) the corresponding yields simulated for the 1994 crop season.

tions were adjusted to produce yield that matched with farmer reported yields in the counties. The three optimum periods when remote sensing data were most effective in adjusting the model simulations are during the early vegetative phase, flowering, and senescence. The availability of cloud-free satellite data during the critical periods generally dictates the optimum situation for model calibration. The success in using Landsat data was encouraging for extending this technique using the lower resolution AVHRR data for crop yield assessment in North Dakota.

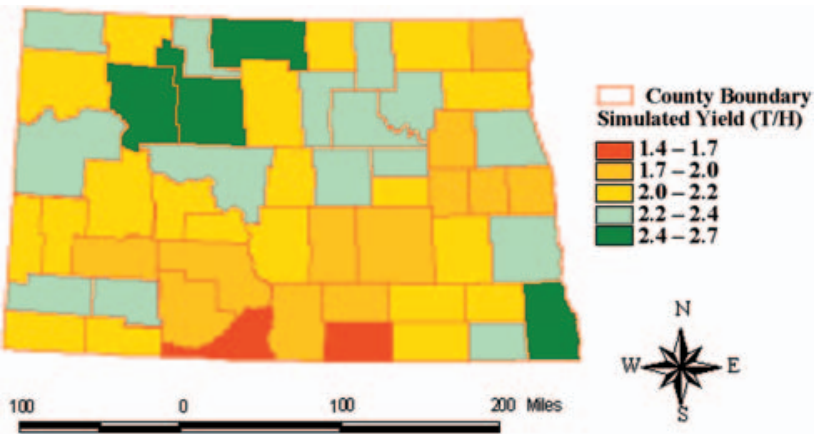

Plate 4. Spring wheat crop yields (tonnes/hectare) for North Dakota for the 1994 crop season.
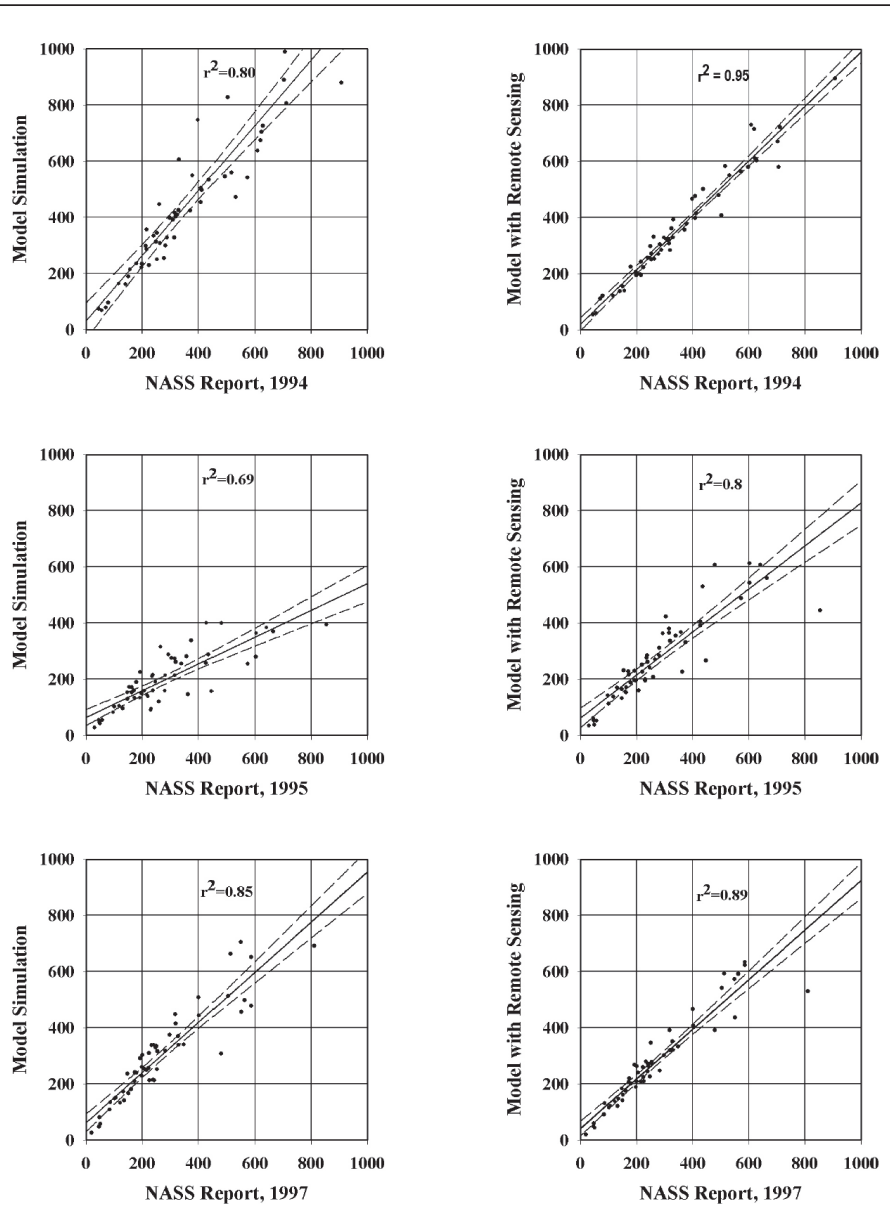

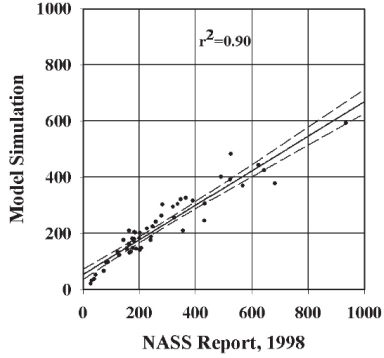

(a)

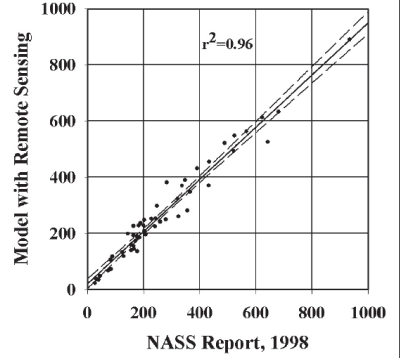

(b)
Figure 2. Regression of NASS reported spring wheat production (tonnes $\times 10^{3}$ ) and model simulations (a) without remote sensing inputs and (b) with inputs from remote sensing.

The 1-km resolution of the AVHRR data was obviously not suitable for spring wheat classification. However, the signature extension technique developed from a combination of Landsat classification and AVHRR data was suitable for developing a spring wheat classification for predominate wheat areas. Crop growth characteristics were monitored from these selected areas to represent the county. Plant disease and other yield reducing factors at the local level cannot be detected due to the low resolution. Crop water stress conditions that retard growth and promote early senescence can be detected because they usually occur at regional scales. Simulations conducted at the county level were found to be suitable, and a four-year analysis of 
county-level yields suggests that this method improved spring wheat crop production estimates. Results of the simulations with and without the use of remote sensing data suggest that remotely sensed data improves the consistency of the predictions, and that significantly better yields can be determined prior to crop harvest using remote sensing data.

\section{Acknowledgments}

The authors wish to acknowledge Mr. Rick Mueller of USDA/ NASS for assistance provided in the classification of the spring wheat using the Landsat TM data. USDA/NASS, Spatial Research Section assisted in acquiring the crop statistical data and their support is acknowledged. Mr. Galen Hart and Dr. Craig Daughtry are acknowledged for their critical review of the manuscript. The U.S. Department of Agriculture, Agriculture Research Service and the National Agricultural Statistics Service funded this project.

\section{References}

Addiscott, T.M., and R.J. Wagenet, 1985. Concept of solute leaching in soils: Review of modeling approaches, Journal of Soil Science, 36:411-424.

AgRISTARS Program, 1981. AgRISTARS: Agriculture and Resources Inventory Surveys through Aerospace Remote Sensing, Annual Report-Fiscal Year 1980, NASA, Lyndon B. Johnson Space Center, Houston, Texas, $59 \mathrm{p}$.

Allen, R., G.A. Hanuschak, and M.E. Craig, 1994. Forecasting crop acreages and yield in the face of and in spite of floods, Crop Yield Forecasting Methods, Proceedings of the Seminar Villefranche-sur-Mer, 24-27 October, Villefranche-sur-Mer, France, pp. 87-110.

Asrar, G., E.T. Kanemasu, T.D. Jackson, and J.R. Pinter, 1985. Estimation of total above-ground phytomass production using remotely sensed data, Remote Sensing of Environment, 17:211-220.

Bauer, M.E., C.T.S. Daughtry, and V.C. Vanderbilt, 1980. Spectralagronomic relationships of corn, soybean, and wheat canopies, Proceedings of the International Colloquium on Spectral Signatures of Objects in Remote Sensing, 08-11 September, Avignon, France, $21 \mathrm{p}$.

Boatwright, G.O., and V.S. Whitefield, 1986. Early warning and crop condition assessment research, IEEE Transactions on Geosciences and Remote Sensing, GE-24(1):56-64.

Bryant, K.J., V.W. Benson, J.R. Kiniry, J.R. Williams, and R.D. Lacewell, 1992. Simulating corn yield response to irrigation timings: Validation of the EPIC model. Journal of Production Agriculture, 5:237-242.

Cook, P.W., R. Mueller, and P.C. Doraiswamy, 1996. Southeastern North Dakota Landsat TM crop mapping project, Proceedings of the Annual Convention \& Exhibition, ASPRS/ACSM, 22-25 April, Baltimore, Maryland (American Society for Photogrammetry and Remote Sensing, Bethesda, Maryland), $1: 600-614$

Daughtry, C.S.T., K.P. Gallo, and M.E. Bauer, 1983. Spectral estimation of solar radiation intercepted by corn canopies. Agronomy Journal, 75:527-531.

Daughtry, C.S.T., K.P. Gallo, L.L. Biehl, E.T. Kanemasu, G. Asrar, B.L. Blad, J.M. Norman, and B.R. Gardner, 1984. Spectral estimates of agronomic characteristics of crops, Proceedings of the 10th International Symposium on Machine Processing of Remotely Sensed Data, 12-14 April, LARS/Purdue University, West Lafayette, Indiana, pp. 348-356.

Doraiswamy, P.C., T. Hodges, and D.E. Phinney, 1979. Crop Yield Literature for AgRISTARS Crops Corn, Soybeans, Wheat, Barley, Sorghum, Rice, Cotton and Sunflowers, AgRISTARS Technical Report SR-L9-00405, Lockheed Electronics Company, Inc., Houston, Texas, $105 \mathrm{p}$.

Doraiswamy, P.C., and P.W. Cook, 1995. Spring wheat yield assessment using NOAA AVHRR data, Canadian Journal of Remote Sensing, 21(1):43-51.
Doraiswamy, P.C., S. Hollinger, T.R. Sinclair, A. Stern, B. Akhmedov, and J. Pruger, 2001. Application of MODIS derived parameters for regional yield assessment, Proceedings, Remote Sensing for Agriculture, Ecosystems, and Hydrology III, 17-21 September, Toulouse, France, CD-ROM 4542-1:1-8.

Edwards, D.R., V.W. Benson, J.R. Williams, T.C. Daniels, J. Lemunyon, and R.G. Gilbert, 1994. Use of the EPIC model to predict runoff transport of surface-applied inorganic fertilizer and poultry manure constituents, Transactions of the ASAE, 37(2):403-409.

Engel, T., G. Hoogenboom, J.W. Jones, and P.W. Wilkens, 1997. AEGIS/WIN: A computer program for the application of crop simulation models across geographic areas, Agronomy Journal, 89(6):919-928.

Gallo, K.P., C.T.S. Daughtry, and M.E. Bauer, 1985. Spectral estimators of absorbed photosynthetically active radiation in corn canopies, Remote Sensing of Environment, 17:221-232.

Goward, S.N., D. Dye, A. Kerber, and V. Kalb, 1987. Comparison of north and south biomass from AVHRR observations, Geocarto International, 1:27-39.

Groten, S.M.E., 1993. NDVI-crop monitoring and early yield assessment of Brukina Faso, International Journal of Remote Sensing, 14(8):1495-1515.

Guerif, M., S. de Brisis, and B. Seguin, 1993. Combined NOAAAVHRR and SPOT-HRV data for assessing crop yields of semiarid environments, EARsel Advances in Remote Sensing, 2(2):110-123.

Hixson, M.M., B.J. Davis, and M.E. Bauer, 1981. Sampling Landsat classifications for crop area estimation, Photogrammetric Engineering \& Remote Sensing, 47(9):1343-1348.

Jackson, R.D., and P.J. Pinter, Jr., 1986. Spectral responses of architecturally different wheat canopies, Remote Sensing of Environment, 20:43-56.

Maas, S.J., 1988. Using satellite data to improve model estimates of crop yield, Agronomy Journal, 80:655-662.

-, 1993. Parameterized model of gramineous crop growth: II. Within-season simulation calibration, Agronomy Journal, 85:354-358.

Maas, S.J., M.S. Moran, and R.D. Jackson, 1992. Combining remote sensing and modeling for regional resource monitoring, Part II: A simple model for estimating surface evaporation and biomass production, Technical Papers, ASPRS/CSM/RT92 Convention, 02-08 August, Washington, D.C. (American Society for Photogrammetry and Remote Sensing, Bethesda, Maryland), pp. 225-234.

Maas, S.J., M.S. Moran, A.M. Weltz, and J.H. Blanford, 1993. Model for simulating surface evaporation and biomass production using routine meteorological and remote sensing data, Technical Papers, 1993 ACSM/ASPRS Convention, 16-19 February, New Orleans, Louisiana (American Society for Photogrammetry and Remote Sensing, Bethesda, Maryland), pp. 212-221.

MacDonald, R.B. (editor), 1979. The LACIE Symposium, Proceedings of Technical Sessions, 23-26 October 1978, NASA, Lyndon B. Johnson Space Center, Houston, Texas, 1125 p.

Malingreau, J.P., 1986. Global vegetation dynamics: Satellite observations over Asia, International Journal of Remote Sensing, 7:1121-1146

Meisinger, J.J., W.L. Hargrove, R.L. Mickelsen, J.R. Williams, and V.W. Benson, 1991. Effects of cover crops on groundwater quality, Cover Crops for Clean Water (H.L. Hargrove, editor), Soil and Water Conservation Society, Ankeny, Iowa, pp. 57-68.

Moulin, S., A. Fisher, G. Edieu, and R. Delcolle, 1995. Temporal variation in satellite reflectances at field and regional scales compared with values simulated by linking crop growth and SAIL models, Remote Sensing of Environment, 54:261-272.

Myers, V.L., 1983. Remote sensing applications in agriculture, Manual of Remote Sensing, Second Edition (R.N. Colwell, editor), American Society of Photogrammetry, Falls Church, Virginia, $2: 2111-2218$.

NDASS, 1995. North Dakota Agricultural Statistics, 1995, Ag Statistics No.64, complied by the North Dakota Agricultural Statistics Service, published in cooperation with North Dakota 
State University and the U.S. Department of Agriculture, Fargo, North Dakota, 105 p.

Pinter, P.J., Jr., R.D. Jackson, C.E. Ezra, and H.W. Gausman, 1985. Sun angle and canopy architecture effects on the spectral reflectance of six heat cultivars, International Journal of Remote Sensing, 6:1813-1825.

Prince, S.D., 1991. A model of regional primary production for use with course resolution satelltie data, International Journal of Remote Sensing, 7:1555-1570.

SCS, 1991. State Soil Geographic Database (STATSCO): Data Users' Guide, SCS Miscellaneous Publication No. 1492, USDA Soil Conservation Service, U.S. Government Printing Office, Washington, D.C., 113 p.

Sinclair, T.R., and Q. Bai, 1997. Analysis of high wheat yields in northwest China, Agricultural Systems, 53:373-385.

Smith, S.J., A.N. Sharpley, and A.D. Nicks, 1990. Evaluation of EPIC nutrient projections using soil profiles for virgin and cultivated lands of the same soil series, EPIC-Erosion/Productivity Impact Calculator: 1. Model Documentation (A.N. Sharpley and J.R. Williams, editors), USDA Technical Bulletin No. 1768, U.S. Department of Agriculture, Washington, D.C., pp. 217-219.

Steiner, J.L., J.R. Williams, and O.R. Jones, 1987. Evaluation of the EPIC simulation model using a dryland wheat-sorghum-fallow crop rotation, Agronomy Journal, 79(4):732-738.

Stern, A.J., P.C. Doraiswamy, and P.W. Cook, 2001. Spring wheat classification in an AVHRR image by signature extension from a Landsat TM classified image, Photogrammetric Engineering $\&$ Remote Sensing, 67:207-211.
Tanji, K.K., 1982. Modeling of the soil nitrogen cycle, Nitrogen in Agricultural Soils (F.J. Stevenson, editor), American Society of Agronomy, Madison, Wisconsin, pp. 721-772.

Toure, A., D.J. Major, and C.W. Lindwall, 1995. Comparison of five wheat simulation models in southern Alberta, Canadian Journal of Plant Science, 75:61-68.

Tucker, C.J., C. Vanpraet, E. Boerwinkel, and A. Gaston, 1983. Satellite remote sensing of total dry matter production in the Senegalese Sahel, Remote Sensing of Environment, 13:461-474.

Tucker, C.J., and P.J. Sellers, 1986. Satellite remote sensing of primary production, International Journal of Remote Sensing, 7(11):1395-1416.

Verhoef, E., 1984. Light scattering by leaf layers with application to canopy reflectance modeling: The SAIL model, Remote Sensing of Environment, 16:125-145.

Vermote, E., and J.C. Roger, 1996. Radiative transfer modeling for calibration and atmospheric correction, Advances in the Use of NOAA AVHRR for Land Applications (G. D’Souza, A.S. Belward, and J. Malingreau, editors), Kluwer Academic Publishers, Dordrecht, The Netherlands, pp. 49-72.

Williams, J.R., C.A. Jones, and P.T. Dyke, 1984. A modeling approach to determining the relationship between erosion and soil productivity, Transactions of the ASAE, 27:129-144.

Zara, M.P., P.C. Doraiswamy, and C.T.S. Daughtry, 1998. Retrieval and mapping of land surface parameters (LAI and fPAR) from satellite data. 1998 ASPRS-RTI Annual Conference. 30 March03 April, Tampa, Florida (American Society for Photogrammetry and Remote Sensing, Bethesda, Maryland), pp 539-545. 